\title{
Clinicodemographic aspect of resectable pancreatic cancer and prognostic factors for resectable cancer
}

\author{
Kun-Chun Chiang ${ }^{1,2}$, Chun-Nan Yeh ${ }^{3,5^{*}}$, Shir-Hwa Ueng ${ }^{4}$, Jun-Te Hsu' ${ }^{3}$, Ta-Sen Yeh ${ }^{3}$, Yi-Yin Jan ${ }^{3}$, \\ Tsann-Long Hwang ${ }^{3}$ and Miin-Fu Chen ${ }^{3}$
}

\begin{abstract}
Background: Pancreatic adenocarcinoma (PCA) is one of the most lethal human malignancies, and radical surgery remains the cornerstone of treatment. After resection, the overall 5 -year survival rate is only $10 \%$ to $29 \%$. At the time of presentation, however, about $40 \%$ of patients generally have distant metastases and another $40 \%$ are usually diagnosed with locally advanced cancers. The remaining $20 \%$ of patients are indicated for surgery on the basis of the results of preoperative imaging studies; however, about half of these patients are found to be unsuitable for resection during surgical exploration. In the current study, we aimed to determine the clinicopathological characteristics that predict the resectability of PCA and to conduct a prognostic analysis of PCA after resection to identify favorable survival factors.

Methods: We retrospectively reviewed the medical files of 688 patients (422 men and 266 women) who had undergone surgery for histopathologically proven PCA in the Department of Surgery at Chang Gung Memorial Hospital in Taiwan from 1981 to 2006. We compared the clinical characteristics of patients who underwent resection and patients who did not undergo resection in order to identify the predictive factors for successful resectability of PCA, and we conducted prognostic analysis for PCA after resection.
\end{abstract}

Results: A carbohydrate antigen 19-9 (CA 19-9) level of $37 \mathrm{U} / \mathrm{ml}$ or greater and a tumor size of $3 \mathrm{~cm}$ or more independently predicted resectability of PCA. In terms of survival after resection, PCA patients with better nutritional status (measured as having an albumin level greater than $3.5 \mathrm{~g} / \mathrm{dl}$ ), radical resection, early tumor stage and betterdifferentiated tumors were associated with favorable survival.

Conclusions: Besides traditional imaging studies, preoperative CA 19-9 levels and tumor size can also be used to determine the resectability of PCA. Better nutritional status, curative resection, early tumor stage and well-

differentiated tumors predict the favorable prognosis of PCA patients after resection.

\section{Background}

Pancreatic adenocarcinoma (PCA) is one of the most lethal human malignancies and ranks as the eighth and ninth most common causes of cancer-related mortality worldwide for men and women, respectively [1]. In the United States in 2008, 37,680 new cases of PCA were diagnosed, and 34,290 PCA-related deaths occurred [2]. The incidence-to-mortality ratio was nearly $1: 1$, illustrating the

\footnotetext{
* Correspondence: yehchunnan@gmail.com

${ }^{3}$ General Surgery Department, Chang Gung Memorial Hospital, Fu-Hsing Street, Kwei-Shan Taoyuan 333, Taiwan

${ }^{5}$ Department of Surgery, Fu-Hsing Street, Kwei-Shan Taoyuan, Taiwan

Full list of author information is available at the end of the article
}

lethality of PCA. The overall 5-year survival rate of patients with PCA is estimated to be approximately $1 \%$ to $4 \%$, a percentage range that is likely related to the aggressive characteristics of PCA, such as early local spread and metastasis and resistance to radiotherapy and most systemic chemotherapies [3]. Currently, radical surgical resection is the cornerstone of treatment. After resection, the overall 5year survival rate is only $10 \%$ to $29 \%$ [4-6]. However, previous studies have shown that, at the time of presentation, about $40 \%$ of patients have distant metastases and another $40 \%$ are diagnosed with locally advanced cancers $[2,3,7]$. The remaining $20 \%$ of patients are indicated for surgery on the basis of the results of preoperative imaging studies;

\section{Biomed Central}


however, about half of these patients are found to be unsuitable for resection during surgical exploration [8-12]. Unnecessary surgical exploration may, in turn, lead to increased surgical risk and healthcare costs and may delay systemic treatment [13].

Therefore, accurate preoperative prediction of PCA resectability is crucial to facilitating appropriate management of PCA patients. In the past few years, researchers have attempted to address this issue and have found that preoperative measurement of carbohydrate antigen 19-9 (CA 19-9) level, endoscopic ultrasonography (EUS), computed tomography $(\mathrm{CT})$ and staging laparoscopy may enhance the accuracy of prediction of resectability before surgery [14-18].

Herein we retrospectively review the medical files of 688 PCA patients who underwent surgery at our hospital from 1981 to 2006 and identified the predictive factors for resectability of PCA by comparing the clinical characteristics of patients who underwent resection with those of patients who did not undergo resection. Furthermore, we also investigated the prognostic factors for favorable PCA outcomes following resection.

\section{Methods}

We retrospectively reviewed the medical files of 688 patients who had undergone surgery for histopathologically proven PCA in the Department of Surgery at Chang Gung Memorial Hospital in Taipei, Taiwan, from 1981 to 2006. This retrospective study was approved by the local institutional review board of Chang Gung Memorial Hospital (clinical study no. 94-955B).

Resection was defined as pancreatectomy (Whipple operation or distal pancreatectomy), regardless of the status of pancreatic resection margin. The patients comprised 422 men and 266 women with a median age of 64 years (range, 14 to 93 years). Of these patients, 230 underwent resection (the resection group), and the remaining 458 patients were unable to undergo resection because of portal vein invasion or carcinomatosis (the no-resection group). Surgical mortality was defined as death within 1 month of surgery. Laboratory tests were conducted 1 day before surgery. Serum CA 19-9 and carcinoembryonic antigen (CEA) levels were measured by radioimmunoassay. Tumors were preoperatively evaluated by abdominal ultrasonography, endoscopic retrograde cholangiopancreatography (ERCP), percutaneous transhepatic cholangiography (PTC), CT, magnetic resonance imaging with cholangiopancreatography (MRCP) and angiography, as appropriate. Tumor stage was defined according to the pathological tumor node metastasis (pTNM) classification proposed by the Union for International Cancer Control (UICC). Stages I and II represent early-stage PCA, and stages III and IV represent advancedstage PCA. Patients with a tumoral resection margin or lymph node metastasis were given adjuvant chemotherapy consisting of a systemic 5-fluorouracil- or gemcitabinebased regimen. Adjuvant radiotherapy was conducted by intraoperative radiotherapy, external beam radiotherapy and/or brachytherapy in patients with either a positive section margin or local recurrence. The followup period ranged from 1 to 169.4 months, and, during follow-up, abdominal CT, chest X-ray, MRCP and tumor marker measurement were performed as appropriate. In terms of tumor size, we chose $3 \mathrm{~cm}$ as the cutoff value to investigate its impact on the resectablity of pancreatic cancer based on our own experience.

\section{Statistical analysis}

All data are presented as the proportion (\%) of patients or as means with standard deviations. Numerical data were compared using independent Student's $t$-tests. Nominal data were compared using Pearson's $\chi^{2}$ test or forward stepwise multiple logistic regression, as appropriate. Survival rates were calculated and plotted using the Kaplan-Meier method. Clinicopathological variables, including demographic data, laboratory data, clinical features, pathological features and operative findings, were selected for survival analysis. We performed survival analysis using the logrank test and multivariate analysis using the Cox proportional hazards model. All statistical analyses were performed using the SPSS computer software package (version 10.0; Chicago, IL, USA). A $P$-value less than 0.05 was considered statistically significant.

\section{Results}

\section{Survival of PCA patients}

The median follow-up time for all patients in this study was 6.5 months (range, 1 to 169.4 months). For the resection group, the median follow-up time was 13 months (range, 1 to 169.4 months) and, for the no-resection group, the median follow-up time was 4.9 months (range, 1 to 65.7 months). Ninety-seven patients were excluded from the survival analysis because of lack of follow-up data or death within 1 month of surgery. The overall 1-, 3- and 5-year survival rates for the remaining 591 PCA patients were $29.7 \%, 8.8 \%$ and $5.1 \%$, respectively. Patients in the resection group showed significantly better survival than patients in the no-resection group (Figure 1). The overall 3-year survival rate was significantly higher in the resection group $(22.6 \%)$ than in the no-resection group $(1.1 \%)(P<0.0001)$. In addition, the PCA resection rate has increased significantly in our hospital over the past 3 decades, from, respectively, $16 \%$ to $27.7 \%$ to $48.8 \%$ for 1981 to 1999,1991 to 2000 and 2001 to $2006(P<0.0001)$.

\section{Predictive factors for resectability of PCA}

Table 1 summarizes the clinicopathological features of the 688 PCA patients. There were 230 patients in the resection 


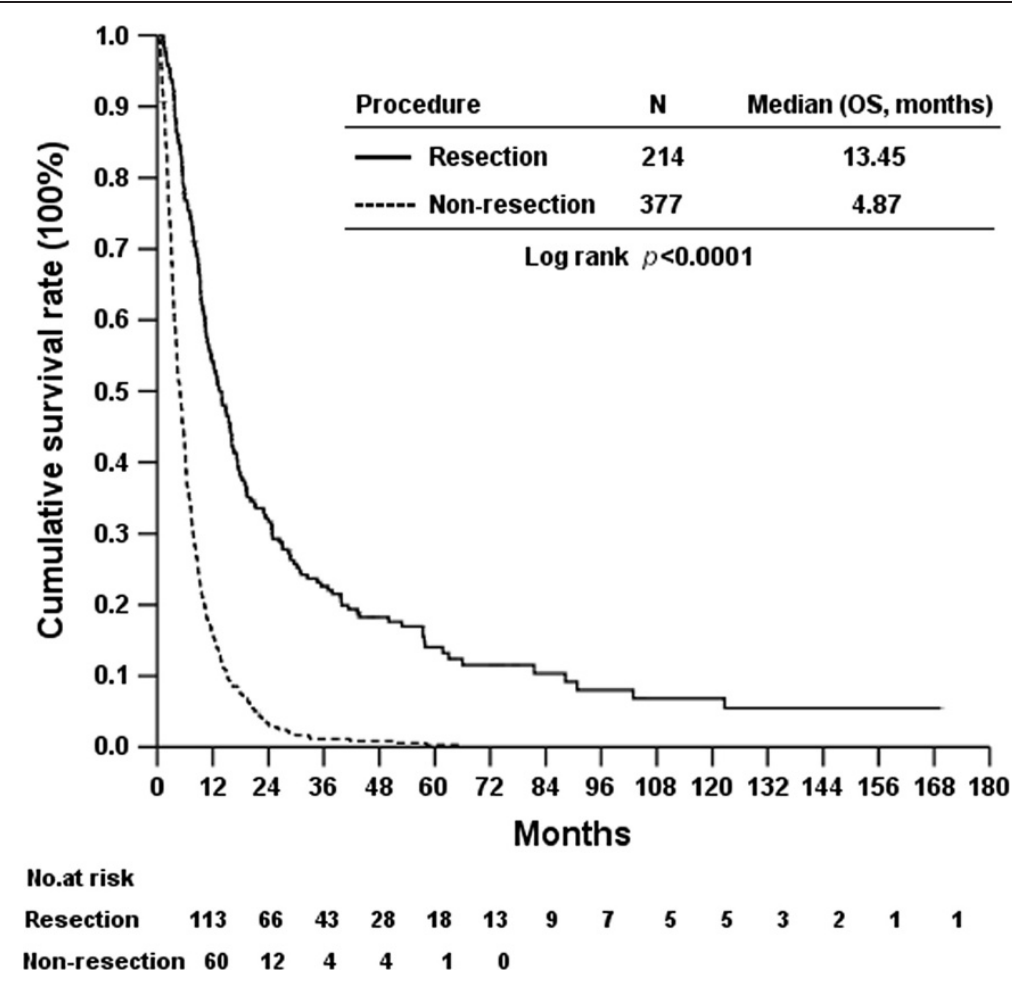

Figure 1 The difference of overall survival rates between 214 pancreatic cancer patients who underwent pancreatic resection and 377 pancreatic cancer patients who did not undergo pancreatic resection.

group and 458 patients in the no-resection group. The mean age in the resection group was significantly lower than that in the no-resection group $(P=0.047)$, and the resection group had a greater proportion of patients ages 65 years or younger $(P=0.015)$. The gender ratio in the two groups was similar. No differences were observed between the two groups with regard to preoperative physical examination findings, but patients in the noresection group tended to be asymptomatic before the operation $(P=0.018)$. Tumor distribution (head or of the pancreas or not) was also similar in the two groups. Patients in the resection group showed higher albumin levels than those in the no-resection group $(3.77 \pm 0.65 \mathrm{~g} / \mathrm{dl}$ versus $3.63 \pm 0.17 \mathrm{~g} / \mathrm{dl} ; P=0.025)$. Furthermore, the proportion of patients with albumin levels greater than $3.5 \mathrm{~g} / \mathrm{dl}$ in the resection group was higher than that in the noresection group $(P=0.02)$. The average of preoperative aspartate aminotransferase (AST) level was higher in the resection group than in the no-resection group. The bilirubin levels were similar in both groups. With regard to the serum levels of the tumor marker CA 19-9, we found lower mean CA 19-9 levels in the resection group than in the no-resection group, but the difference was not statistically significant. In addition, the proportion of patients with CA 19-9 levels above $37.0 \mathrm{U} / \mathrm{ml}$ in the noresection group was higher than that in the resection group
$(P=0.007)$. Similarly, CEA levels were higher in the noresection group, and a higher proportion of patients in the no-resection group had CEA levels greater than $5 \mathrm{ng} / \mathrm{ml}$. The mean tumor size in the no-resection group was $6.2 \pm$ $3.5 \mathrm{~cm}$, and that in the resection group was $4.61 \pm 3.6 \mathrm{~cm}$. Because we had set $3 \mathrm{~cm}$ as the cutoff value for tumor size, the no-resection group obviously showed a higher rate of tumors over $3 \mathrm{~cm}$ than the resection group. Moreover, the no-resection group had shorter operation times, fewer postoperative complications and lower mortality rates than the resection group did.

All significant predictive factors obtained in the univariate analysis (Table 1) were included in our multivariate analysis, which was performed using a logistic regression method. Only CA 19-9 level $<37$ and tumor size $<3 \mathrm{~cm}$ were independent predictive factors for resectability of PCA.

\section{Factors influencing the survival of PCA patients after resection}

Univariate analysis (Table 2) indicated that women had a better prognosis than men $(P=0.02)$, with overall 3 - and 5 -year survival rates of $29.9 \%$ and $23.1 \%$, respectively, for women and 3- and 5-year overall survival rates of $18.3 \%$ and $8.6 \%$, respectively, for men. An albumin level greater than $3.5 \mathrm{~g} / \mathrm{dl}$ was a favorable prognostic factor for survival 
Table 1 Characteristics of pancreatic ductal adenocarcinoma in patients with either resectable or nonresectable tumors

\begin{tabular}{|c|c|c|c|}
\hline Characteristics & $\begin{array}{c}\text { Resectable } \\
\text { tumor }(n=230)\end{array}$ & $\begin{array}{l}\text { Non-resectable } \\
\text { tumor }(n=458)\end{array}$ & $P$ value \\
\hline Age (years) & $62.1 \pm 11.1$ & $64.0 \pm 12.0$ & 0.047 \\
\hline$<65$ & $136(59.1 \%)$ & $226(49.3 \%)$ & 0.015 \\
\hline$\geq 65$ & $94(40.9 \%)$ & $232(50.7 \%)$ & \\
\hline Sex & & & 0.749 \\
\hline Male & $143(62.2 \%)$ & 279 (60.9\%) & \\
\hline Women & 87 (37.8\%) & 179 (37.1\%) & \\
\hline Symptoms & & & 0.018 \\
\hline Yes & $225(97.8 \%)$ & 457 (99.8\%) & \\
\hline No & $5(2.2 \%)$ & $1(0.2 \%)$ & \\
\hline Physical findings & & & 0.979 \\
\hline Yes & $166(72.2 \%)$ & $331(72.3 \%)$ & \\
\hline No & 64 (27.8\%) & 127 (27.7\%) & \\
\hline Bilirubin (mg/dl) & $7.5 \pm 9.1$ & $7.2 \pm 8.5$ & 0.574 \\
\hline$\leq 1.3$ & $80(36.5)$ & $177(42.3)$ & 0.155 \\
\hline$>1.3$ & 139 (63.5) & $241(57.7)$ & \\
\hline Albumin (g/dl) & $3.77 \pm 0.65$ & $3.63 \pm 0.71$ & 0.025 \\
\hline$\leq 3.5$ & 61 (33.0\%) & 149 (43.3\%) & 0.020 \\
\hline$>3.5$ & $124(67.0 \%)$ & 195 (56.7\%) & \\
\hline AST (U/L) & $112.9 \pm 146.8$ & $84.8 \pm 99.2$ & 0.011 \\
\hline$\leq 68$ & $110(49.1 \%)$ & $250(60.1 \%)$ & 0.008 \\
\hline$>68$ & 114 (50.9\%) & 166 (39.9\%) & \\
\hline CEA (ng/ml) & $6.1 \pm 8.1$ & $13.5 \pm 48.0$ & 0.008 \\
\hline$\leq 5$ & $115(67.6 \%)$ & $180(58.4 \%)$ & 0.047 \\
\hline$>5$ & 55 (32.4\%) & $128(41.6 \%)$ & \\
\hline CA 19-9 (U/ml) & $1,229.6 \pm 4,680.4$ & $1,616.4 \pm 5,253.1$ & 0.425 \\
\hline$\leq 37$ & 48 (27.1\%) & $46(16.5 \%)$ & 0.007 \\
\hline$>37$ & 129 (72.9\%) & $232(83.5 \%)$ & \\
\hline Operation time (minutes) & $426.0 \pm 155.3$ & $219.2 \pm 172.4$ & $<0.0001$ \\
\hline$\leq 240$ & $31(13.9 \%)$ & $285(68.3 \%)$ & $<0.0001$ \\
\hline$>240$ & $192(86.1 \%)$ & $132(31.7 \%)$ & \\
\hline Complication & & & 0.003 \\
\hline Yes & $55(23.9 \%)$ & $67(14.6 \%)$ & \\
\hline No & $175(76.1 \%)$ & $391(85.4 \%)$ & \\
\hline Death & & & 0.017 \\
\hline Yes & $7(3.0 \%)$ & $36(7.6 \%)$ & \\
\hline No & $223(97.0 \%)$ & $423(92.4 \%)$ & \\
\hline Tumor size (cm) & $4.6 \pm 3.6$ & $6.2 \pm 3.5$ & $<0.0001$ \\
\hline$\leq 3$ & $94(42.7 \%)$ & $24(15.8 \%)$ & $<0.0001$ \\
\hline$>3$ & $126(57.3 \%)$ & $128(84.2 \%)$ & \\
\hline Location & & & 0.111 \\
\hline Head of pancreas & $165(71.7 \%)$ & $301(65.7 \%)$ & \\
\hline Not at head of pancreas & $65(28.3 \%)$ & $157(34.3 \%)$ & \\
\hline
\end{tabular}

Table 1 Characteristics of pancreatic ductal adenocarcinoma in patients with either resectable or nonresectable tumors (Continued)

\begin{tabular}{lccc}
\hline Differentiation & & & 0.0002 \\
Well & $83(36.1 \%)$ & $134(29.3 \%)$ & \\
Moderate & $105(45.7 \%)$ & $173(37.8 \%)$ & \\
Poor & $35(15.2 \%)$ & $103(22.5 \%)$ & \\
Others & $7(3.0 \%)$ & $48(10.5 \%)$ & \\
Post-op C/T & & & $<0.0001$ \\
Yes & $121(52.6 \%)$ & $163(35.6 \%)$ & \\
No & $109(47.7 \%)$ & $295(64.4 \%)$ & \\
Post-op R/T & & & 0.255 \\
Yes & $17(7.4 \%)$ & $46(10.0 \%)$ & \\
No & $213(92.6 \%)$ & $412(90.0 \%)$ & \\
\hline
\end{tabular}

AST: aspartate aminotransferase; CEA: carcinoembryonic antigen; CA 19-9: carbohydrate antigen 19-9; Post-op C/T: postoperative chemotherapy; Post-op $\mathrm{R} / \mathrm{T}$ : postoperative radiotherapy; Others: mixed tumor differentiation.

after PCA resection $(P=0.024)$. Other factors, such as nontumoral resection margin, bilirubin levels of $1.3 \mathrm{mg} / \mathrm{dl}$ or less, CA 19-9 levels of $37 \mathrm{U} / \mathrm{ml}$ or less, no lymph node metastasis, early pTNM stage and well-differentiated tumors, were also associated with a better prognosis. On the other hand, age, preoperative physical examination findings and preoperative biochemical data (including levels of amylase, lipase and the tumor marker CEA) were not associated with patient survival after resection of PCA. Interestingly, we found that tumor location, operative procedure and portal vein resection were not related to patient survival after PCA resection.

In the analysis of the significant factors using the multivariate Cox proportional hazards method, we identified albumin levels greater than $3.5 \mathrm{~g} / \mathrm{dl}$ (Figure 2a), nontumoral resection margin (Figure 2b), well-differentiated tumors (Figure 2c) and early pTNM stage (Figure $2 \mathrm{~d}$ ) as favorable prognostic factors after resection of PCA.

\section{Discussion}

Pancreatic cancer ranks as the fifth most common cause of cancer-related mortality worldwide, and patients with PCA generally have a very poor prognosis [3]. Radical surgical resection is the most effective treatment for PCA, because pancreatic tumors tend to respond poorly to both radiotherapy and chemotherapy. According to the results of previous studies, however, only $20 \%$ of PCA patients are considered suitable for resection prior to surgical exploration, and during surgical exploration, half of these patients are found to be unsuitable for resection because of the advanced stage of the tumor [7].

Recent improvements in radiological imaging techniques have decreased the rate of unnecessary surgical exploration; however, the current state of PCA resectability 
Table 2 Univariate analysis of factors influencing the overall survival of the 214 PAC patients

\begin{tabular}{|c|c|c|c|c|c|c|}
\hline Factors & Data $(n)$ & $\begin{array}{l}\text { Median survival } \\
\text { (months) }\end{array}$ & $\begin{array}{l}95 \% \mathrm{Cl} \text { of } \\
\text { median }\end{array}$ & 1 year & 3 years & $P$-value \\
\hline \multirow[t]{3}{*}{ Age (years) } & & & & & & 0.068 \\
\hline & $\leq 65(130)$ & 16.08 & 13.23 to 18.93 & 26.6 & 15.3 & \\
\hline & $>65(26)$ & 10.28 & 9.05 to 11.53 & 16.8 & 12.0 & \\
\hline \multirow[t]{3}{*}{ Sex } & & & & & & 0.020 \\
\hline & Male (125) & 11.18 & 8.51 to 13.85 & 18.3 & 8.6 & \\
\hline & Female (89) & 16.57 & 14.05 to 19.09 & 29.9 & 23.1 & \\
\hline \multirow[t]{3}{*}{ Symptoms } & & & & & & 0.007 \\
\hline & Positive (209) & 13.05 & 10.30 to 15.50 & 21.2 & 12.4 & \\
\hline & Negative (5) & NA & & 80.0 & 80.0 & \\
\hline \multirow[t]{3}{*}{ Bilirubin (mg/dl) } & & & & & & 0.009 \\
\hline & $\leq 1.3(73)$ & 17.39 & 12.19 to 22.59 & 26.7 & 26.9 & \\
\hline & $>1.3(130)$ & 12.69 & 10.14 to 15.24 & 20.9 & 8.2 & \\
\hline \multirow[t]{3}{*}{ Albumin (g/dl ) } & & & & & & 0.024 \\
\hline & $\leq 3.5(54)$ & 9.04 & 5.50 to 12.58 & 15.2 & 10.2 & \\
\hline & $>3.5(117)$ & 15.75 & 12.45 to 19.05 & 25.4 & 16.7 & \\
\hline \multirow[t]{3}{*}{ Amylase (U/L) } & & & & & & 0.216 \\
\hline & $\leq 300(82)$ & 13.05 & 8.77 to 17.33 & 19.3 & 13.4 & \\
\hline & $>300(12)$ & 19.27 & 0.00 to 63.26 & 50.0 & 10.0 & \\
\hline \multirow[t]{3}{*}{ Lipase (U/L) } & & & & & & 0.255 \\
\hline & $\leq 300(47)$ & 12.26 & 8.48 to 16.05 & 13.4 & 8.9 & \\
\hline & $>300(30)$ & 16.04 & 6.03 to 26.05 & 26.7 & 16.0 & \\
\hline \multirow[t]{3}{*}{ CEA (ng/ml) } & & & & & & 0.159 \\
\hline & $\leq 5(109)$ & 15.85 & 12.19 to 19.52 & 23.8 & 17.5 & \\
\hline & $>5(52)$ & 10.42 & 7.04 to 13.80 & 24.7 & 6.1 & \\
\hline \multirow[t]{3}{*}{ CA 19-9 (U/ml) } & & & & & & 0.044 \\
\hline & $\leq 37(44)$ & 19.43 & 8.50 to 30.37 & 32.6 & 22.3 & \\
\hline & $>37(125)$ & 13.05 & 10.08 to 16.02 & 19.7 & 9.6 & \\
\hline \multirow[t]{4}{*}{ Surgical procedure } & & & & & & 0.115 \\
\hline & Whipple (119) & 12.79 & 9.90 to 15.69 & 21.2 & 10.8 & \\
\hline & PPPD (39) & 13.05 & 7.25 to 18.85 & 23.7 & 13.5 & \\
\hline & Others (56) & 17.19 & 11.81 to 22.57 & 25.1 & 25.1 & \\
\hline \multirow[t]{3}{*}{ Resection margin $(\mathrm{cm})$} & & & & & & 0.001 \\
\hline & Nontumoral & 15.42 & 13.12 to 17.72 & 58.8 & 27.3 & \\
\hline & Tumoral & 9.67 & 8.15 to 11.19 & 42.1 & 10.5 & \\
\hline \multirow[t]{5}{*}{ Tumor location } & & & & & & 0.096 \\
\hline & Head (152) & 12.79 & 10.34 to 15.24 & 21.3 & 11.12 & \\
\hline & Uncinate process (20) & 19.13 & 3.79 to 34.47 & 32.8 & 32.8 & \\
\hline & Body (32) & 19.27 & 9.75 to 28.80 & 22.7 & 22.7 & \\
\hline & Tail (10) & 8.19 & 2.18 to 14.20 & 20.0 & NA & \\
\hline \multirow[t]{3}{*}{ Portal vein resection } & & & & & & 0.249 \\
\hline & Performed (12) & 9.27 & 0.00 to 19.54 & 16.7 & 0.0 & \\
\hline & Not performed (202) & 13.45 & 10.62 to 16.29 & 23.0 & 15.1 & \\
\hline \multirow[t]{2}{*}{ Tumor size $(\mathrm{cm})$} & $<3(90)$ & 11.89 & 11.89 to 17.83 & 24.6 & 12.7 & 0.874 \\
\hline & $>3(116)$ & 8.02 & 8.02 to 16.30 & 21.9 & 14.5 & \\
\hline
\end{tabular}


Table 2 Univariate analysis of factors influencing the overall survival of the 214 PAC patients (Continued)

\begin{tabular}{|c|c|c|c|c|c|c|}
\hline \multirow[t]{2}{*}{ Nodal status } & Negative (108) & 18.87 & 14.04 to 23.70 & 34.0 & 23.1 & \multirow[t]{2}{*}{$<0.000$} \\
\hline & Positive (105) & 9.4 & 7.98 to 10.82 & 11.1 & 4.7 & \\
\hline \multirow[t]{3}{*}{ TNM staging } & I (32) & 62.99 & 18.01 to 107.97 & 56.7 & 51.0 & \multirow[t]{3}{*}{$<0.0001$} \\
\hline & $\|(76)$ & 15.78 & 12.77 to 18.79 & 24.9 & 12.3 & \\
\hline & III (106) & 9.4 & 7.98 to 10.82 & 11.1 & 4.7 & \\
\hline \multirow[t]{4}{*}{ Tumor differentiation } & Well (76) & 26.4 & 21.09 to 31.77 & 39.5 & 28.3 & \multirow[t]{4}{*}{$<0.0001$} \\
\hline & Moderate (98) & 10.32 & 8.39 to 12.25 & 14.0 & 7.9 & \\
\hline & Poor (35) & 9.47 & 5.67 to 13.27 & 12.1 & 3.0 & \\
\hline & Undifferentiated (5) & 5.46 & 4.60 to 6.32 & 40.0 & 0.0 & \\
\hline \multirow[t]{3}{*}{ Post-op radiotherapy } & & & & & & \multirow[t]{3}{*}{0.849} \\
\hline & Performed (17) & 17.56 & 10.45 to 24.67 & 17.6 & 11.8 & \\
\hline & Not Performed (197) & 12.79 & 9.79 to 15.80 & 23.1 & 14.3 & \\
\hline \multicolumn{7}{|l|}{ Post-op chemotherapy } \\
\hline & Performed (119) & 14.93 & 11.70 to 18.16 & 22.7 & 10.4 & \\
\hline & Not Performed (95) & 10.32 & 7.44 to 13.20 & 22.5 & 19.5 & \\
\hline
\end{tabular}

CEA: carcinoembryonic antigen; CA 19-9: carbohydrate antigen 19-9; NA: not applicable; TNM: tumor, node, metastasis; PPPD: pylorus preserving pancreaticoduodenectomy.

prediction remains unsatisfactory [19-21]. Thus far the method of choice for diagnosing and staging PCA is thinsection, contrast-enhanced, triple-phase CT [22,23]. This method can result in a $90 \%$ to $100 \%$ predictive value for the unresectability of PCA [14,24-26], but only a $52 \%$ to 96\% predictive value for resectability has been reported $[8,11,24,27,28]$. Other methods, such as EUS or $2-\left[{ }^{18} \mathrm{~F}\right]-$ fluoro-2-deoxy-D-glucose positron emission tomography (FDG-PET) is also unable to provide satisfactory predictive value regarding resectablity before surgery [16,29-32]. Taken together, these studies demonstrate that no imaging studies can yet provide a complete picture of the preoperative status of PCA to clinical physicians, and thus further investigation of potential ancillary predictive factors is warranted.

In this study, we identified the clinicopathological features of PCA patients that may be useful for predicting the resectability of PCA. Physicians can use these ancillary predictive factors, in combination with traditional imaging studies, to determine the resectability of PCA with increased accuracy.

In the current study, patients in the resection group were, on average, 2 years younger than those in the noresection group (62 versus 64 years old; $P=0.047$ ), and the resection group comprised a greater proportion of patients ages 65 years or younger $(P=0.015)$. This observation suggests that there may be a 2 -year period during which PCA progresses from being resectable to becoming unresectable. We also found that CA 19-9 level $37 \mathrm{U} / \mathrm{ml}$ or less and tumor size $3 \mathrm{~cm}$ or less were independent factors predicting the resectability of PCA. Furthermore, patients in the resection group had longer operation times. The results of our study suggest that both CA $19-9(\leq 37 \mathrm{U} / \mathrm{ml})$ and tumor size $(\leq 3 \mathrm{~cm})$ could be used as ancillary parameters to determine the resectability of PCA (odds ratios, 2.458 and 3.155, respectively).

Serological markers of malignancy are widely used as adjuncts to the results of imaging studies for diagnosing malignancy and predicting prognosis. CA 19-9, initially detected by Koprowaki et al. [33], is the most wellestablished tumor marker for PCA, with higher sensitivity and specificity than CEA, CA 50, and CA 242 [34-36]. Some recent studies have emphasized the importance of preoperative CA 19-9 levels in determining the resectability of PCA [15,37]. Maithel et al. recommended staging laparoscopy for patients whose CA 199 levels exceeded $130.0 \mathrm{U} / \mathrm{ml}$ and who were diagnosed with resectable PCA as indicated by radiography [17]. In our study, a lower percentage of patients in the resection group had preoperative CA 19-9 levels greater than $37 \mathrm{U} / \mathrm{ml}$, while CEA levels failed to independently predict the resectability of PCA, an observation that is in line with previous reports [34-36]. Although many studies have investigated the relationship between tumor size and prognosis in PCA [38-40], few studies have associated tumor size with resectability. In the current study, we found that tumor size (cutoff value, 3 $\mathrm{cm}$ ) could be used to predict the resectability of PCA independently.

For decades, researchers have attempted to determine the factors predictive of favorable outcomes after resection of PCA. In contrast to the study conducted by Schmidt et al., our present study did not show that CEA level could be used as a prognostic factor for PCA following tumor 


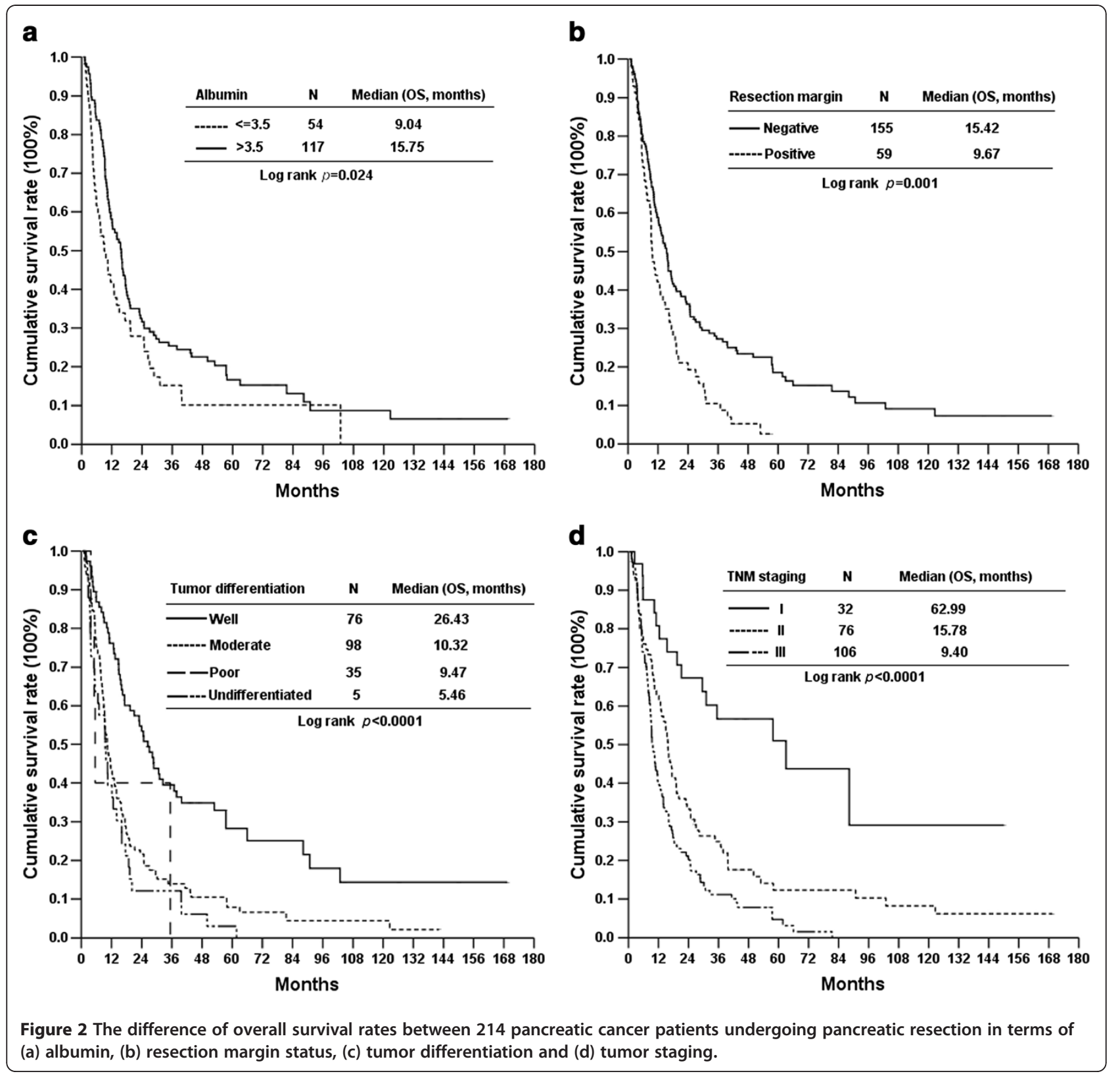

resection [41]; however, researchers in other studies have reported findings similar to ours [38,42]. CA 19-9 level has been widely reported to be a prognostic factor for PCA after tumor resection [40,43,44]. Schmidt et al. [41] also demonstrated that increased bilirubin predicted unfavorable survival outcomes after PCA resection. In our study CEA, however, neither CA 19-9 nor bilirubin independently indicated a worse outcome after PCA resection. Interestingly, in addition to well-established indicators of survival, such as resection margin status, tumor stage and histological differentiation, we identified serum albumin as an independent prognostic factor after resection of PCA in our study. Albumin has previously been shown to be related to the prognosis of cancer patients $[45,46]$. In pancreatic cancer, Ruiz-Tovar et al. reported that the preoperative serum albumin level (with the cutoff value set at $2.8 \mathrm{~g} / \mathrm{dl}$ ) could be used as a prognostic factor for PCDA [47]. Malnutrition has long been deemed a severe problem involving complex mechanisms in cancer patients [48]. The lower serum albumin concentration in advanced cancer patients may be due to the release of some cytokines such as interleukin 6 or TNF, to suppression of hepatocyte production of albumin, or to increased capillary permeability to albumin by the tumor or its surrounding tissues $[46,49]$. For example, in conditions of liver metastasis existing, Kupffer cells in the liver would be stimulated to 
produce interleukin 6 and TNF. Taken together, serum albumin could be deemed a good indicator of cancer survival. In this study, albumin levels greater than $3.5 \mathrm{~g} / \mathrm{dl}$ were found to be associated with a better prognosis for PCA survival after resection.

\section{Conclusion}

On the basis of our study results, we propose that preoperative CA 19-9 levels and tumor size less than $3 \mathrm{~cm}$ can be used as auxiliary parameters, in combination with traditional imaging studies, to determine the resectability of PCA. Furthermore, albumin levels, resection margin status, tumor stage and histological differentiation can be used as prognostic factors for survival after resection of PCA.

\section{Consent statement}

This study has been approved by Chang Gung memorial hospital IRB board. The approved IRB number is 94-955B. A copy of the approval of IRB is available for review by the Editor-in-Chief of this journal.

\section{Abbreviation}

TNF: Tumor necrosis factor.

\section{Competing interests}

The authors declare that they have no competing interests.

\section{Authors' contributions}

K-CC wrote the manuscript, S-HU carried out the pathological examination, J-TH helped write the manuscript, T-SY helped write the manuscript,Y-YJ participated in data collection, T-LH helped write the manuscript, M-FC helped review this manuscript. C-NY finalized the manuscript. All authors read and approved the final manuscript.

\section{Foundation}

This work was supported by Chang Gung Medical Research Program (CMRP) grant $280271 \mathrm{G}$ and $280272 \mathrm{G}$ to Dr. Kun-Chun Chiang.

\section{Author details}

'General Surgery Department, Chang Gung Memorial Hospital, 222, Mai-Chin Road, Keelung 204, Taiwan. ${ }^{2}$ Graduate Institute of Clinical Medical Sciences, College of Medicine, Chang Gung University, 259 Wen-Hwa 1st Road, Kwei-Shan, Tao-Yuan 333, Taiwan. ${ }^{3}$ General Surgery Department, Chang Gung Memorial Hospital, Fu-Hsing Street, Kwei-Shan Taoyuan 333, Taiwan. ${ }^{4}$ Department of Pathology, Chang Gung Memorial Hospital, Fu-Hsing Street, Kwei-Shan Taoyuan 333, Taiwan. ${ }^{5}$ Department of Surgery, Fu-Hsing Street, Kwei-Shan Taoyuan, Taiwan.

Received: 20 January 2012 Accepted: 21 March 2012 Published: 4 May 2012

\section{References}

1. Jemal A, Bray F, Center MM, Ferlay J, Ward E, Forman D: Global cancer statistics. CA Cancer J Clin 2011, 61:69-90.

2. American Cancer Society: Cancer Facts \& Figures 2008. Atlanta: American Cancer Society; 2008. http://www.cancer.org/acs/groups/content/@nho/ documents/document/2008caffinalsecuredpdf.pdf.

3. Jemal A, Siegel R, Ward E, Murray T, Xu J, Thun MJ: Cancer statistics, 2007. CA Cancer J Clin 2007, 57:43-66.

4. Trede M, Schwall G, Saeger HD: Survival after pancreatoduodenectomy: 118 consecutive resections without an operative mortality. Ann Surg 1990, 211:447-458
5. Yeo CJ, Cameron JL, Sohn TA, Lillemoe KD, Pitt HA, Talamini MA, Hruban RH, Ord SE, Sauter PK, Coleman J, Zahurak ML, Grochow LB, Abrams RA: Six hundred fifty consecutive pancreaticoduodenectomies in the 1990s: pathology, complications, and outcomes. Ann Surg 1997, 226:248-260.

6. Nitecki SS, Sarr MG, Colby TV, van Heerden JA: Long-term survival after resection for ductal adenocarcinoma of the pancreas. Is it really improving? Ann Surg 1995, 221:59-66.

7. Haller DG: New perspectives in the management of pancreas cancer. Semin Oncol 2003, 30:3-10.

8. Ellsmere J, Mortele K, Sahani D, Maher M, Cantisani V, Wells W, Brooks D, Rattner D: Does multidetector-row CT eliminate the role of diagnostic laparoscopy in assessing the resectability of pancreatic head adenocarcinoma? Surg Endosc 2005, 19:369-373.

9. Gulliver DJ, Baker ME, Cheng CA, Meyers WC, Pappas TN: Malignant biliary obstruction: efficacy of thin-section dynamic CT in determining resectability. AJR Am J Roentgenol 1992, 159:503-507.

10. Prokesch RW, Chow LC, Beaulieu CF, Bammer R, Jeffrey RB Jr: Isoattenuating pancreatic adenocarcinoma at multi-detector row $\mathrm{CT}$ : secondary signs. Radiology 2002, 224:764-768.

11. Saldinger PF, Reilly M, Reynolds K, Raptopoulos V, Chuttani R, Steer ML Matthews JB: Is CT angiography sufficient for prediction of resectability of periampullary neoplasms? J Gastrointest Surg 2000, 4:233-237.

12. Spitz FR, Abbruzzese JL, Lee JE, Pisters PW, Lowy AM, Fenoglio CJ, Cleary KR, Janjan NA, Goswitz MS, Rich TA, Evans DB: Preoperative and postoperative chemoradiation strategies in patients treated with pancreaticoduodenectomy for adenocarcinoma of the pancreas. J Clin Oncol 1997, 15:928-937.

13. Parsons CM, Sutcliffe $\mathrm{L}$, Bold RJ: Preoperative evaluation of pancreatic adenocarcinoma. J Hepatobiliary Pancreat Surg 2008, 15:429-435.

14. Clarke DL, Thomson SR, Madiba TE, Sanyika C: Preoperative imaging of pancreatic cancer: a management-oriented approach. J Am Coll Surg 2003, 196:119-129.

15. Zhang S, Wang YM, Sun CD, Lu Y, Wu LQ: Clinical value of serum CA19-9 levels in evaluating resectability of pancreatic carcinoma. World J Gastroenterol 2008, 14:3750-3753.

16. Ho JM, Eysselein VE, Stabile BE: The value of endoscopic ultrasonography in predicting resectability and margins of resection for periampullary tumors. Am Surg 2008, 74:1026-1029.

17. Maithel SK, Maloney S, Winston C, Gonen M, D'Angelica MI, Dematteo RP, Jarnagin WR, Brennan MF, Allen PJ: Preoperative CA 19-9 and the yield of staging laparoscopy in patients with radiographically resectable pancreatic adenocarcinoma. Ann Surg Oncol 2008, 15:3512-3520.

18. Klauss M, Mohr A, von Tengg-Kobligk H, Friess $H$, Singer $R$, Seidensticker $P$, Kauczor HU, Richter GM, Kauffmann GW, Grenacher L: A new invasion score for determining the resectability of pancreatic carcinomas with contrast-enhanced multidetector computed tomography. Pancreatology 2008, 8:204-210.

19. Varadhachary GR, Tamm EP, Crane C, Evans DB, Wolff RA: Borderline resectable pancreatic cancer. Curr Treat Options Gastroenterol 2005, 8:377-384.

20. Takhar AS, Palaniappan P, Dhingsa R, Lobo DN: Recent developments in diagnosis of pancreatic cancer. BMJ 2004, 329:668-673.

21. Misek DE, Patwa TH, Lubman DM, Simeone DM: Early detection and biomarkers in pancreatic cancer. J Natl Compr Canc Netw 2007, 5:1034-1041.

22. Delbeke $D$, Pinson CW: Pancreatic tumors: role of imaging in the diagnosis, staging, and treatment. J Hepatobiliary Pancreat Surg 2004 $11: 4-10$.

23. Sahani DV, Shah ZK, Catalano OA, Boland GW, Brugge WR: Radiology of pancreatic adenocarcinoma: current status of imaging. J Gastroenterol Hepatol 2008, 23:23-33.

24. Diehl SJ, Lehmann KJ, Sadick M, Lachmann R, Georgi M: Pancreatic cancer: value of dual-phase helical CT in assessing resectability. Radiology 1998, 206:373-378.

25. Legmann P, Vignaux O, Dousset B, Baraza AJ, Palazzo L, Dumontier I, Coste J, Louvel A, Roseau G, Couturier D, Bonnin A: Pancreatic tumors: comparison of dual-phase helical CT and endoscopic sonography. AJR Am J Roentgenol 1998, 170:1315-1322.

26. Lu DS, Reber HA, Krasny RM, Kadell BM, Sayre J: Local staging of pancreatic cancer: criteria for unresectability of major vessels as revealed by 
pancreatic-phase, thin-section helical CT. AJR Am J Roentgenol 1997, 168:1439-1443.

27. Steinberg WM, Barkin J, Bradley EL 3rd, Di Magno E, Layer P: Workup of a patient with a mass in the head of the pancreas. Pancreas 1998, 17:24-30

28. Conlon KC, Dougherty E, Klimstra DS, Coit DG, Turnbull AD, Brennan MF: The value of minimal access surgery in the staging of patients with potentially resectable peripancreatic malignancy. Ann Surg 1996, 223:134-140.

29. Rose DM, Delbeke D, Beauchamp RD, Chapman WC, Sandler MP, Sharp KW, Richards WO, Wright JK, Frexes ME, Pinson CW, Leach SD:

${ }^{18}$ Fluorodeoxyglucose-positron emission tomography in the management of patients with suspected pancreatic cancer. Ann Surg 1999, 229:729-738.

30. Sendler A, Avril N, Helmberger H, Stollfuss J, Weber W, Bengel F, Schwaiger M, Roder JD, Siewert JR: Preoperative evaluation of pancreatic masses with positron emission tomography using ${ }^{18} \mathrm{~F}$-fluorodeoxyglucose: diagnostic limitations. World J Surg 2000, 24:1121-1129.

31. Delbeke D, Rose DM, Chapman WC, Pinson CW, Wright JK, Beauchamp RD, Shyr Y, Leach SD: Optimal interpretation of FDG PET in the diagnosis, staging and management of pancreatic carcinoma. J Nucl Med 1999, 40:1784-1791.

32. Nakamoto Y, Higashi T, Sakahara H, Tamaki N, Kogire M, Imamura M, Konishi J: Contribution of PET in the detection of liver metastases from pancreatic tumours. Clin Radiol 1999, 54:248-252.

33. Koprowski H, Steplewski Z, Mitchell K, Herlyn M, Herlyn D, Fuhrer P: Colorectal carcinoma antigens detected by hybridoma antibodies. Somatic Cell Genet 1979, 5:957-971.

34. Wu X, Lu XH, Xu T, Qian JM, Zhao P, Guo XZ, Yang XO, Jiang WJ: [The diagnostic value of serum carcinoma markers, fecal K-ras and p53 gene mutation in pancreatic cancers] [in Chinese]. Zhonghua Nei Ke Za Zhi 2005, 44:741-744.

35. Okusaka T, Okada S, Sato T, Wakasugi H, Saisho H, Furuse J, Ishikawa O, Matsuno S, Yokoyama S: Tumor markers in evaluating the response to radiotherapy in unresectable pancreatic cancer. Hepatogastroenterology 1998, 45:867-872.

36. Liao Q, Zhao YP, Yang YC, Li L, Long X, Han SM: Combined detection of serum tumor markers for differential diagnosis of solid lesions located at the pancreatic head. Hepatobiliary Pancreat Dis Int 2007, 6:641-645.

37. Kiliç M, Göçmen E, Tez M, Ertan T, Keskek M, Koç M: Value of preoperative serum CA 19-9 levels in predicting resectability for pancreatic cancer. Can J Surg 2006, 49:241-244.

38. Han SS, Jang JY, Kim SW, Kim WH, Lee KU, Park YH: Analysis of long-term survivors after surgical resection for pancreatic cancer. Pancreas 2006, 32:271-275.

39. Moon HJ, An JY, Heo JS, Choi SH, Joh JW, Kim Yl: Predicting survival after surgical resection for pancreatic ductal adenocarcinoma. Pancreas 2006, 32:37-43.

40. Shimada K, Sakamoto Y, Sano T, Kosuge T: Prognostic factors after distal pancreatectomy with extended lymphadenectomy for invasive pancreatic adenocarcinoma of the body and tail. Surgery 2006, 139:288-295.

41. Schmidt CM, Powell ES, Yiannoutsos CT, Howard TJ, Wiebke EA, Wiesenauer CA, Baumgardner JA, Cummings OW, Jacobson LE, Broadie TA, Canal DF, Goulet RJ Jr, Curie EA, Cardenes H, Watkins JM, Loehrer PJ, Lillemoe KD, Madura JA: Pancreaticoduodenectomy: a 20-year experience in 516 patients. Arch Surg 2004, 139:718-727.

42. Ni XG, Bai XF, Mao YL, Shao YF, Wu JX, Shan Y, Wang CF, Wang J, Tian YT, Liu Q, Xu DK, Zhao P: The clinical value of serum CEA, CA19-9, and CA242 in the diagnosis and prognosis of pancreatic cancer. Eur J Surg Oncol 2005, 31:164-169.

43. Ferrone CR, Finkelstein DM, Thayer SP, Muzikansky A, Fernandez-del Castillo C, Warshaw AL: Perioperative CA19-9 levels can predict stage and survival in patients with resectable pancreatic adenocarcinoma. J Clin Oncol 2006, 24:2897-2902.

44. Berger AC, Meszoely IM, Ross EA, Watson JC, Hoffman JP: Undetectable preoperative levels of serum CA 19-9 correlate with improved survival for patients with resectable pancreatic adenocarcinoma. Ann Surg Oncol 2004, 11:644-649.

45. Sirott MN, Bajorin DF, Wong GY, Tao Y, Chapman PB, Templeton MA, Houghton AN: Prognostic factors in patients with metastatic malignant melanoma: a multivariate analysis. Cancer 1993, 72:3091-3098.
46. McMillan DC, Watson WS, O'Gorman P, Preston T, Scott HR, McArdle CS: Albumin concentrations are primarily determined by the body cell mass and the systemic inflammatory response in cancer patients with weight loss. Nutr Cancer 2001, 39:210-213.

47. Ruiz-Tovar J, Martín-Pérez E, Fernández-Contreras ME, Reguero-Callejas ME, Gamallo-Amat C: Impact of preoperative levels of hemoglobin and albumin on the survival of pancreatic carcinoma [English and Spanish]. Rev Esp Enferm Dig 2010, 102:631-636.

48. von Meyenfeldt M: Cancer-associated malnutrition: an introduction. Eur J Oncol Nurs 2005, 9(Suppl 2):S35-S38.

49. Barber MD, Ross JA, Fearon KC: Changes in nutritional, functional, and inflammatory markers in advanced pancreatic cancer. Nutr Cancer 1999, 35:106-110.

doi:10.1186/1477-7819-10-77

Cite this article as: Chiang et al: Clinicodemographic aspect of resectable pancreatic cancer and prognostic factors for resectable cancer. World Journal of Surgical Oncology 2012 10:77.

\section{Submit your next manuscript to BioMed Central and take full advantage of:}

- Convenient online submission

- Thorough peer review

- No space constraints or color figure charges

- Immediate publication on acceptance

- Inclusion in PubMed, CAS, Scopus and Google Scholar

- Research which is freely available for redistribution 